\title{
THE BOUND CARBOHYDRATE OF BOVINE SEMINAL PLASMA
}

\author{
S. BARONOS* \\ ARC Unit of Reproductive Physiology and Biochemistry, \\ University of Cambridge
}

(Received 29th Fune 1970)

\begin{abstract}
Summary. Galactose has been identified as the main bound carbohydrate of bovine seminal plasma. It was detected chromatographically and determined enzymatically (by galactose dehydrogenase) in acidhydrolysed material. Bound galactose was shown to occur mainly in the non-dialysable portion of bovine seminal plasma in amounts varying from 30 to $150 \mathrm{mg} / 100 \mathrm{ml}$ seminal plasma. It occurs in a protein-bound form, and is secreted by the seminal vesicles.
\end{abstract}

\section{INTRODUCTION}

Bull seminal plasma, in common with that of other mammals, contains a considerable amount of carbohydrate which occurs partly free and partly bound. The free carbohydrate is present mainly in the form of fructose and originates in the seminal vesicles and ampullae (Mann, 1946, 1964). The bound carbohydrate occurs in the form of polysaccharides (Mann \& Rottenberg, 1966).

The main purpose of the present study was to identify the sugars which compose the bound carbohydrate of the bovine seminal plasma. Evidence is presented to show that the predominant sugar occurring in the bound form is galactose and that bound galactose originates in the seminal vesicle, the same organ which secretes fructose.

\section{MATERIALS AND METHODS}

\section{Collection of semen and of the seminal-vesicle secretion}

Semen from adult bulls was collected by an artificial vagina (Walton, 1945), and the seminal plasma separated from the spermatozoa by centrifugation. Most experiments were carried out with pooled seminal plasma but, on two occasions, instead of pooled material individual semen samples were used; the electrical stimulation method (Lutwak-Mann \& Rowson, 1953; Davies, Mann \& Rowson, 1957) was also used in order to collect semen fractions from an adult bull and to obtain an ejaculate from a 6-month-old calf. The seminal-vesicle secretion was obtained at autopsy.

\footnotetext{
* Present address: 10 Filiou Str. N Filothei, Athens, Greece.
} 
Separation of free and bound carbohydrate

Seminal plasma or vesicular fluid was dialysed at 3 to $5^{\circ} \mathrm{C}$ against glassdistilled water, which was changed five times at 12-hr intervals. The nondialysable portion was concentrated in vacuo at 40 to $50^{\circ} \mathrm{C}$ to the original volume of the seminal plasma. The dialysable portion was concentrated in vacuo to half the original volume of the seminal plasma. For the analysis of neutral sugars, samples of both the dialysable and non-dialysable portions, each containing about 0.5 to $0.8 \mathrm{mg}$ orcinol-reactive carbohydrate $/ \mathrm{ml}$ were hydrolysed with $1 \mathrm{~N}-\mathrm{H}_{2} \mathrm{SO}_{4}$ in sealed tubes for $6 \mathrm{hr}$ at 105 to $110^{\circ} \mathrm{C}$. For the liberation of hexosamines, samples were hydrolysed with $1 \mathrm{~N}-\mathrm{HCl}$ for $12 \mathrm{hr}$ at 100 to $105^{\circ} \mathrm{C}$. Sialic acid was liberated by hydrolysis for $1 \mathrm{hr}$ in $0.1 \mathrm{~N}-\mathrm{H}_{2} \mathrm{SO}_{4}$ at $80^{\circ} \mathrm{C}$.

Glycogen, together with any 'galactogen' (i.e. polysaccharide composed solely of galactose) was separated by the procedure of alkaline hydrolysis and ethanol precipitation (Pflüger, 1903; Somogyi, 1934). The final precipitate was dissolved in $2 \mathrm{ml}$ water and hydrolysed with $1 \mathrm{~N}-\mathrm{H}_{2} \mathrm{SO}_{4}$ before enzymatic determination of glucose and galactose.

\section{Preparation of material for paper chromatography}

Before chromatography, ions were removed by means of an ion-exchangeresin column containing Dowex AG-1 $\left(\mathrm{OAc}^{-}\right)$and Amberlite IR-120 (H+) (Mann \& Rottenberg, 1966). Following deionization, the combined effluents were concentrated in a rotary evaporator at 40 to $50^{\circ} \mathrm{C}$ to near dryness. The residue was dissolved with a small amount of water and an aliquot of the solution, corresponding to about $100 \mu \mathrm{g}$ orcinol-reactive carbohydrate, was applied to the paper. Ethyl acetate:pyridine: water $(8: 2: 1$ by vol) was used as the solvent system, and the spots produced by sugars, sugar alcohols and other silver-reducing substances were detected by the method of Trevelyan, Proctor \& Harrison (1950).

\section{Glucose, galactose, fructose and total carbohydrate}

Glucose was estimated by the glucose oxidase-tolidine method (Middleton \& Griffiths, 1957). Galactose was estimated by galactose dehydrogenase supplied by G. F. Boehringer \& Soehne GMBH. Fructose was estimated according to the colorimetric method of Roe (1934) as adapted to semen by Mann (1946). Total carbohydrate was measured by the orcinol method (Vasseur, 1948). All these estimations were carried out on deionized material.

\section{Hexosamine and sialic acid}

Hexosamine was determined spectrophotometrically according to Cessi \& Piliego (1960). Sialic acid, free and bound (liberated by hydrolysis), was determined according to Warren (1954).

\section{Nitrogen}

Total nitrogen was determined by the micro-Kjeldahl procedure using Markham's distillation apparatus (King \& Wootton, 1956). 


\section{RESULTS}

Preliminary paper chromatographic analysis carried out on samples of nonfractionated bovine seminal plasma which had been subjected to acid hydrolysis revealed the presence of a surprisingly large amount of galactose varying from 30 to $150 \mathrm{mg} / 100 \mathrm{ml}$. However, no galactose was found in the protein-free extracts prepared from seminal plasma by means of $\mathrm{Ba}(\mathrm{OH})_{2}$ and $\mathrm{ZnSO}_{4}$. The possibility that galactose may have arisen as an artifact from galactosamine or from fructose was immediately excluded by employing identical procedures of hydrolysis and deionization to solutions of pure galactosamine, glucosamine and fructose.

Chromatography was repeated using fractionated seminal plasma in the form of (i) dialysable non-hydrolysed, (ii) dialysable and acid-hydrolysed, and (iii) non-dialysable but acid-hydrolysed material. The dialysable non-hydrolysed material contained mainly fructose and also some inositol and sorbitol; this was in agreement with the earlier observations of Mann (1946, 1954), Hartree (1957) and King, Isherwood \& Mann (1958). The same dialysable fraction after hydrolysis was also found to contain a small amount of galactose. On the other hand, the non-dialysable and acid-hydrolysed material was shown to contain a much larger amount of galactose, as well as a little mannose. The discovery that the bulk of the bound carbohydrate in bovine seminal plasma consists mainly of galactose led us to consider the possible sources of that sugar. One possibility was that galactose occurs in the seminal plasma bound to a protein. The other possibility was that it may be present in the form of a 'galactogen'-like polysaccharide. In order to explore both these possibilities, one aliquot of the non-dialysable portion of bull seminal plasma was hydrolysed with $\mathrm{H}_{2} \mathrm{SO}_{4}$ while another one was subjected to alkaline hydrolysis and ethanol precipitation (Pflüger, 1903; Somogyi, 1934). The acid hydrolysates prepared from two different specimens of bull seminal plasma contained 37 and $132 \mathrm{mg}$ galactose $/ 100 \mathrm{ml}$, respectively. After ethanol precipitation, the alkaline hydrolysates prepared from the same material contained neither glycogen nor galactogen. From this, it can be concluded that galactose occurs in seminal plasma in a protein-bound form and not as 'galactogen'.

In every sample of bull seminal plasma so far examined, including the electroejaculate of an immature bull calf, galactose was shown to be the principal bound sugar, though on no occasion was it possible to detect any free galactose. The results of analyses of the various neutral sugars, amino-sugars, sialic acid and nitrogen performed on fractionated seminal plasma and vesicular secretion are shown in Table 1. As can be seen, the non-dialysable and acid-hydrolysed portion of bovine seminal plasma contained, in addition to galactose, an appreciable amount of hexosamine and sialic acid. Table 1 also shows that bound galactose is in fact derived mainly from the seminal-vesicle secretion.

In order to investigate the origin of bound galactose, analyses were performed using, instead of semen, separate fractions of an electro-ejaculate collected from an adult bull. In the experiment, the results of which are recorded in Table 2, the combined volume of all the fractions was $16 \mathrm{ml}$. Of this volume, about $7 \mathrm{ml}$ was contributed by the first three fractions and constituted 


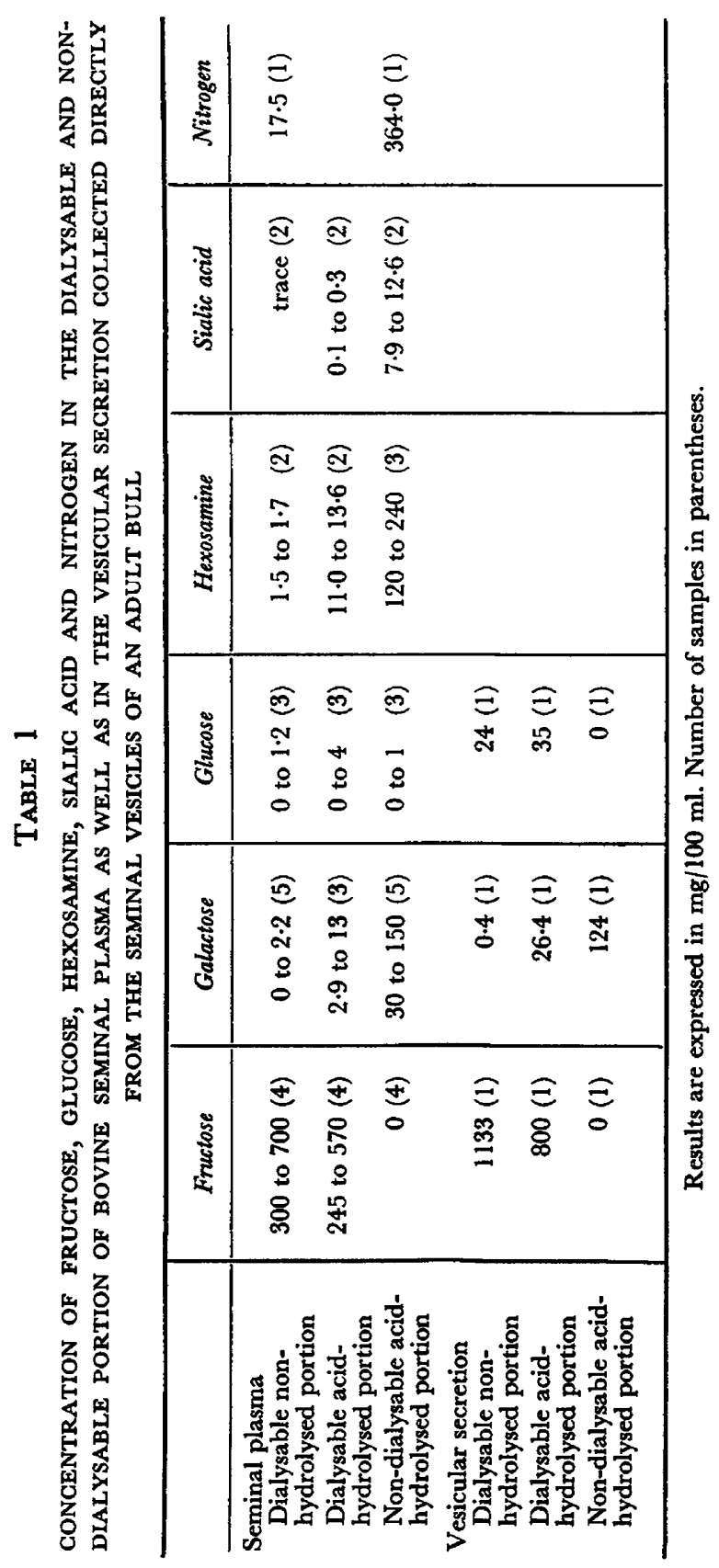


the so-called 'pre-sperm' fraction, that is, the secretion of the urethral glands. This fraction was sperm-free and contained neither fructose nor bound galactose but did contain an appreciable amount of hexosamine and sialic acid, as in the observations by Lutwak-Mann \& Rowson (1953). Fractions 4 and 5 represented mainly the sperm-rich fraction. They contained little fructose and little bound galactose, hexosamine and sialic acid. The remaining two fractions (6 and 7), which constitute the 'post-sperm' fraction derived mainly from the seminal vesicle, had not only a high concentration of fructose but also of bound galactose.

TABLE 2

GONGENTRATION OF NITROGEN, HEXOSAMINE, SIALIC AGID, FRUGTOSE AND BOUND GALAGTOSE IN SEVEN FRAGTIONS OF BULL SEMEN, GOLLECTED IN ORDER OF THEIR APPEARANGE DURING ELEGTRO-EJAGULATION

\begin{tabular}{|c|c|c|c|c|c|c|c|}
\hline & \multicolumn{7}{|c|}{ Fraction of ejaculate } \\
\hline & 1st & $2 n d$ & $3 r d$ & 4 th & 5 th & 6 th & 7th \\
\hline Volume & 1.8 & $2 \cdot 4$ & $2 \cdot 6$ & 1.5 & 1.8 & $3 \cdot 3$ & $2 \cdot 6$ \\
\hline Sperm density & - & - & 0.26 & 1.042 & 1.728 & 1.600 & 0.728 \\
\hline Fructose & - & - & $\ldots$ & $52 \cdot 0$ & $167 \cdot 0$ & $380 \cdot 0$ & $290 \cdot 0$ \\
\hline Galactose & - & - & - & $18 \cdot 0$ & $59 \cdot 0$ & $66 \cdot 0$ & $61 \cdot 0$ \\
\hline Hexosamine & $53 \cdot 0$ & $51 \cdot 0$ & $51 \cdot 0$ & 74.0 & $116 \cdot 0$ & 121.0 & 111.0 \\
\hline Sialic acid & $15 \cdot 0$ & $10 \cdot 0$ & $9 \cdot 8$ & & $23 \cdot 3$ & 44.5 & $29 \cdot 0$ \\
\hline Nitrogen & $90 \cdot 0$ & 80.0 & $67 \cdot 0$ & $183 \cdot 0$ & $530 \cdot 0$ & $560 \cdot 0$ & $600 \cdot 0$ \\
\hline
\end{tabular}

Results are expressed in $\mathrm{mg} / 100 \mathrm{ml}$ fraction; volume is expressed in $\mathrm{ml}$; sperm density in $10^{9}$ cells $/$ fraction; other results in $\mathrm{mg} / 100 \mathrm{ml}$.

\section{DISCUSSION}

It has been recognized for some time that mammalian seminal plasma is characterized by a high content of carbohydrate both in free and bound form. In the past, most investigations were directed towards the elucidation of the nature and function of the free carbohydrate. More recently, however, the presence of a small amount of bound galactose in human seminal plasma has been reported by Mann \& Rottenberg (1966). The present study reveals that bovine seminal plasma is extraordinarily rich in bound galactose, so much so that bound galactose can almost be considered as yet another macro-constituent of semen. Most of the bound galactose is contained in the non-dialysable portion of bovine seminal plasma and appears to be present in those parts of the bovine ejaculate which are also rich in fructose. This observation together with the results of direct analysis of seminal-vesicle secretion demonstrates that free fructose and bound galactose are produced in the bull by the same accessory gland, namely, the seminal vesicle.

\section{ACKNOWLEDGMENTS}

I wish to thank Professor T. Mann, F.R.s., for his valuable help and criticism. For the collection of bull semen, I am greatly indebted to Mr L. E. A. Rowson and $\mathrm{Dr}$ H. M. Dott. I am also indebted for a Scholarship to the Organization for Economic Co-operation and Development. 


\section{REFERENCES}

Cessi, G. \& Prlrego, F. (1960) The determination of amino-sugar in the presence of aminoacids and glucose. Biochem. F. 77, 508.

Davies, D. V., Mann, T. \& Rowson, L. E. A. (1957) The effect of nutrition on the onset of male sex hormone activity and sperm formation in monozygous bull calves. Proc. R. Soc. B, 147, 332.

Hartree, E. F. (1957) Inositol in seminal plasma. Biochem. 7. 66, 131.

King, T. E., Isherwood, F. A. \& MANN, T. (1958) Sorbitol in semen. Abstracts of 4th Congr. Biochem., Vienna. Int. Abstr. biol. Sci. Suppl. Abstr. 6-61, 77.

KING, E. J. \& Wootron, I. D. P. (1956) Microanalysis in medical biochemistry. Churchill, London.

Lutwak-ManN, C. \& Rowson, L. E. A. (1953) The chemical composition of the pre-sperm fraction of bull ejaculate obtained by electrical stimulation. F. agric. Sci. 43, 131 .

MANN, T. (1946) Studies of the metabolism of semen. Fructose as a normal constituent of seminal plasma. Site of formation and function of fructose in semen. Biochem. 3. 40, 481.

MANN, T. (1954) On the presence and role of inositol and certain other substances in the seminal vesicle secretion of the boar. Proc. R. Soc. B, 142, 21.

MANn, T. (1964) The biochemistry of semen and of the male reproductive tract, pp. 45, 53, 241. Methuen, London.

MANn, T. \& Rottenberg, D. A. (1966) The carbohydrate of human semen. F. Endocr. 34, 257.

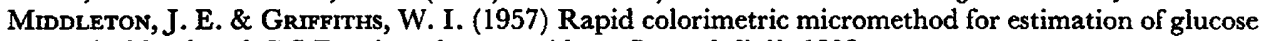
in blood and C.S.F. using glucose oxidase. Br. med. F. ii, 1523.

PrLüger, E. (1903) Ueber den Glykogengehalt der Thiere im Hungerzustend. Pfügers Arch. ges. Physiol. $91,119$.

RoE, J. H. (1934) A colorimetric method for the determination of fructose in blood and urine. F. biol. Chem. $107,15$.

Somogyi, M. (1934) The solubility and preparation of phosphorus and nitrogen free glycogen. F. biol. Chem. 104, 245.

Trevelyan, W. E., Proctor, D. P. \& Harrison, J. S. (1950) Detection of sugar on paper chromatograms. Nature, Lond. 166, 444.

VAsszUR, E. (1948) A spectrophotometric study on the orcinol reaction with carbohydrates. Acta chem. scand. 2, 693.

WaLton, A. (1945) Notes on artificial insemination of sheep, cattle and horses. Holborn Surgical Instrument Co., London.

WARren, L. (1954) The thiobarbituric acid assay of sialic acids. F. biol. Chem. 234, 1971. 